\title{
Değişen Eczacı Rolleri Bağlamında Hastaların Eczacılık Hizmetleri ile İlgili Memnuniyetlerinin Değerlendirilmesi*
}

\author{
Evaluation of Patient Satisfaction with Pharmacy Services in The Context of \\ Changing Pharmacist Roles
}

\author{
Arş. Gör. Muazez DEMIR ${ }^{\text {iD }}{ }^{1}$, Dr. Öğr. Üyesi Erdal EKE ${ }^{\left[D_{2}\right.}$
}

\begin{abstract}
$\ddot{\mathbf{O} z}$
Eczacılık mesleğinin dönüşümü paralelinde değissen eczacı rolleri, sunulan eczacilık hizmetlerinin çeşitlenmesine ve eczacıların sorumluluklarının artmasına yol açmıştır. Sağlık sektörünün bir paydaşı olan eczacıların rollerini değerlendirme noktasında hasta memnuniyeti önemli bir parametredir. Ayrıca hasta memnuniyeti değerlendirme sonuçları, sağlık hizmetlerinin tasarım ve yönetiminde hizmet sağlayıcılara ve politika yapıcılara yol göstermede önemlidir. $\mathrm{Bu}$ çalışmada bireylerin eczacılık hizmetinden memnuniyetleri değerlendirilmiş̧ir. Araştırma evrenini Isparta il merkezinde yaşayan 18 yaş üzeri bireyler oluşturmaktadır. Araştırmada kolayda örnekleme yöntemi kullanılarak 411 katılımcıya ulaşılmıştır. Araştırmada veri toplama aracı olarak, araştırmacı tarafından geliştirilen "Eczacıllk Hizmetlerinin Değerlendirilmesi Anketi”" kullanılmıştır. Bireylerin eczacıların danışmanlıklarından $(2,928)$ orta derecede, eczanenin fiziki şartlarından ve eczacı ile olan iletişim boyutundan $(3,929)$ iyi düzeyde ve ilaç kullanımı bilgilendirme boyutundan $(4,092)$ iyi düzeyde memnun oldukları sonucuna varılmışıtır. Eczacıların klasik görevlerini yerine getirdikleri ancak değişen eczacılık rollerini henüz tam olarak yerine getirmedikleri sonucuna ulaşılmıştır.
\end{abstract}

Anahtar Kelimeler: Serbest eczacı, eczane, eczacılık hizmetleri, hasta memnuniyeti, sağlık politikası

Makale Türü: Araştırma

\begin{abstract}
In parallel to the transformation of the pharmacy profession, the changing pharmacist roles have led to the diversification of the pharmacy services offered and the increasing responsibility of pharmacists. Patient satisfaction is an important parameter in evaluating the role of pharmacists as a stakeholder of the health sector. In addition, the results of patient satisfaction assessment are important in guiding service providers and policy makers in the design and management of health services. In this study, the satisfaction of individuals in pharmacy service was evaluated. The population of research consists of individuals over the age of 18 living in the city center of Isparta. 411 participants were reached by convenience sampling method in the study. In the study, "Pharmacy Services Evaluation Questionnaire" developed by the researcher was used as data collection tool. Individuals were partially satisfied with the counseling roles of pharmacists $(2,93)$, they were found to be highly satisfied with the physical conditions of the pharmacist and the dimension of the contact with the pharmacy $(3,93)$ and dimension of drug use information $(4,09)$. Pharmacists have fulfilled their classical duties but have not yet fulfilled their changing pharmacy roles.
\end{abstract}

Keywords: Community pharmacist, pharmacy, pharmaceutical services, patient satisfaction, health policy

Paper Type: Research

\footnotetext{
*Bu çalıșma sorumlu yazarın yüksek lisans tezinden üretilmiștir.

${ }^{1}$ Muş Alparslan Üniversitesi, Sağlık Yüksekokulu, muazezdemir@sdu.edu.tr.

${ }^{2}$ Süleyman Demirel Üniversitesi, İ̈BF, erdaleke@sdu.edu.tr.
}

Atıf için (to cite): Demir, M. ve Eke, E. (2020). Değişen eczacı rolleri bağlamında hastaların eczacılık hizmetleri ile ilgili memnuniyetlerinin değerlendirilmesi. Afyon Kocatepe Üniversitesi Sosyal Bilimler Dergisi, 22(2), 555-574. 


\section{Giriş}

Dünya Sağlık Örgütü (DSÖ) raporuna göre serbest eczacılar, sağlık kuruluşları ve toplum içinde sayıca fazla olup hasta refahını sağlamak adına hastanın daha kolay ulaşabilecekleri, sağlık konularında danışmanlık alabilecekleri, ilaç yönetimi ve bilgisi konusunda profesyonel kişiler olarak addedilmişlerdir (WHO, 1994, s. 4). Eczacılar, ilaç sunan sağlık hizmeti sunucusu olmaktan çıkıp zamanla sağlığın korunması, geliştirilmesi ve rehabilite edilmesine kadar birçok düzeyde görevi, sorumluluğu ve fonksiyonu yerine getirir olmuşlardır (TEB, 2003, s. 1). Bahsi geçen bu hizmetlerin değerlendirilmesinin yollarından birisi hastaların aldıkları hizmetlere ilişkin algılarının ve memnuniyetlerinin tespit edilmesidir.

$\mathrm{Bu}$ çalışma ile bireylerin eczacılık hizmetlerine ilişkin algıların değerlendirilmesi ve eczacılık hizmetlerinden memnuniyet düzeylerinin tespit edilmesi amaçlanmıştır. Çalışmanın kavramsal çerçeve bölümünde değişen eczacılık hizmetlerinden, eczacının dönüşen rollerinden, sağlık sisteminde eczanelerin konumlandırılmasından ve son olarak hasta memnuniyetinden bahsedilmiştir. Araştırma kısmında hastaların eczacılık hizmetleri ilişkin memnuniyet düzeyleri değerlendirilmiş olup eczacılık hizmetleri üzerinde cinsiyet, yaş, öğrenim durumu ve aylık gelir, kronik hastalık gibi faktörlerin etkili olup olmadığı tespit edilmeye çalışılmıştır.

\section{Eczacı ve Eczacılık Hizmetleri}

\subsection{Değişen Eczacılık Hizmetleri ve Eczacının Dönüşsen Rolü}

İlaç, eczanelerde el üretimiyle yapılan eczalardan seri üretimle üretilen ve pazarlanan eczalara doğru evrilmiştir. Bu gelişim eczacıyı "ilaç yapan" konumdan "ilaç satan" konuma doğru itmiştir (Baytop, 1995, s. 8; White ve Latif, 2006, s. 1409). Ancak 1970'lere gelindiğinde, ilaçtaki sanayileşme ve gelişme ile üretilen daha güçlü kimyasal ilaçların yan etkilerine karşı insanların korunması gerektiği gündeme gelmiştir. Bu sebepten ötürü eczacılara hazır ilaçların doğru kullanımını sağlama noktasında sorumluluklar yüklenmiştir (WHO, 1994, s. 8). Aynı dönemlerde eczacılık mesleği, klinik eczacılık ve farmasötik bakım anlayışları ile yeni bir boyut daha kazanmıştır. Eczacıların hazır ilaçları tedarik etme ve satışa sunma rolleri, bilgi ve yetenekleri doğrultusunda hizmet sunmaya ve son olarak hasta odaklı bakım anlayışına doğru evrilmiştir (Wiedenmayer vd., 2006).

Hastaya yönelik hizmetler döneminin başlangıcı olarak 1960'larda "klinik eczacıllk" kavramının doğuşu kabul edilmektedir (Hepler ve Strand, 1990, s. 534; Aypar vd., 2014, s. 48). Klinik eczacılık, eczacılar tarafından hasta bakımı kapsamında farmakokinetik, terapötik (tedavi bilimi), farmakoloji ve toksikoloji gibi bilimlerin bilimsel prensiplerini hasta yararına kullanılmasını içeren somut bir sağlık bilimi uzmanlığı ya da disiplini olarak tanımlanmaktadır (Ives ve Maddux, 2004, s. 1). Farmasötik bakım ise Berenguer ve arkadaşları (2004, s. 3935) tarafından bir hastanın yaşam kalitesini iyileştirmek veya sürdürmek için pozitif sonuçların elde edilmesi amacıyla ilaç tedavisinin etkin ve kontrollü bir şekilde sağlanması olarak tanımlanmıştır. Güngör (2015, s. 21), farmasötik bakımı kısaca "eczacının tüm bildiklerini hasta yararına kullanması" olarak ifade etmektedir.

Farmasötik bakım ile klinik eczacılık kavramlarına bakıldığında yakından ilişkili oldukları görülmektedir. Hepler (2004, s. 1492) yayınladığı çalışmasında bu iki kavramın birbirini tamamlayıcı hizmetler içerdiğine vurgu yapmıştır. Klinik eczacılık uygulamalarının, farmasötik bakım felsefesini benimsediğini belirtmiştir.

Bu kavramların tanımlarındaki ortak noktalardan birisi, eczacıların hasta odaklı olmaları gerekliliğidir. Hasta odaklılık kavramını eczacıların terapötik bilgi ve deneyimlerini kullanarak hastanın tedavi sürecini başarıya ulaştırmaları, hastayla iletişim içerisinde olmaları ve yönlendirme yapmaları (ACCP, 2008, s. 816) şeklinde tanımlamak mümkündür. Eczacılık mesleğinin dönüşümü içerisinde günümüzdeki hakim anlayışın hasta odaklı hizmet sunumu olduğu ortaya konulmuştur. Bu anlayış ile eczacılarla iletişim, ilacı aç- tok karına kullanın ifadeleri dışında taşınabilir. Eczacıların ilaç etkileşimlerini anlatmaları ve ilaç uyuncunun 
tedavinin seyrini nasıl etkileyebileceğini açıklamaları tedavi sürecinin başarıyla sonuçlanmasına katkı sağlayabilir. Eczacılar aldıkları eğitim neticesinde ek gıda, sağlıklı yaşam gibi konularda yararlı bilgiler sunulmasında güvenilir kaynak olabilirler. Ancak bunlar için eczacının iletişime açık ve hasta odaklı bir anlayışla hizmet sunması önemli bir noktadır.

Klinik eczacılık ile eczacılık tekrardan canlandırılıp meslek yeniden şekillendirilirken (Shirkey, 1977, s. 674) eczacıllğın hasta odaklı bir mesleğe doğru dönüşümünde eczacılar "görünmez" bir sağlık bakım uzmanı olarak tanımlanmışlardır (Adamcik vd., 1986, s. 1187). Klinik eczacılık içerdiği klinik kelimesinden dolayı çoğu zaman hastanede sunulan eczacılık hizmeti olarak algılanmasına rağmen aslında hasta odaklı eczacılık olup serbest eczacıların da yerine getirebileceği bir alan olarak kabul edilmektedir (Aypar vd., 2014, s. 48; Güngör, 2015, s. 28; Eczacinın Sesi Gazetesi).

Serbest eczacılara, değişen eczacılık rolleri bağlamında bireylerin sağlık ihtiyacını yönlendirme, tamamlama ve bu süreçte yetkileri dahilinde sağlık hizmeti sunma noktalarında önemli görev ve sorumluluklar verilmiştir. Barber ve arkadaşları (1994, s. 153), eczacıların değişen ve dönüşen rollerini kısaca şu şekilde açıklamışlardır; eczacıların klasik reçetelerin hazırlanması ve ilaçları hastalara ulaştırma rolleri, tavsiyede bulunmaya, ilaç tedavisini izlemeye, ilacın olumsuz yan etkilerini açıklamaya ve saptamaya, ilaç-besin veya ilaç-ilaç etkileşimlerini anlatmaya kadar genişletilmiştir. Eczacılar artık halkın değişen ihtiyaçlarına, bireylerin sağlık bakım hedeflerine ve sağlık hizmeti sunumdaki değişikliklere yanıt vermek için bu tür çeşitli rollere sahiptir. Bu roller danışmanlık rolü altında toplanılabilir. Ayrıca eczacılara yönelik böyle bir bakış açısı eczacının doğal olarak sağlık meslek profesyoneli olduğunu kanıtlar niteliktedir (TEB, 2007, s. 30).

Eczacıların değiş̧en ve genişleyen bu rolleri serbest eczaneleri günümüz sağlık sistemlerinde önemli paydaşlardan biri haline getirmiştir. Bu değişime uygun olarak serbest eczaneler, sahibi ve mesul müdürü eczacının kendisi olma şartı ile eczacılık mesleğinin kuralları doğrultusunda hastaya ilacı temin etmenin yanında birinci basamak sağlık hizmeti sunulan ve sağlık tüketiminin son durağı olarak da tanımlanan, İyi Eczacılık Uygulamaları'nın gereğini yerine getirerek kamusal faydayı en üst düzeyde sağlamayı hedefleyen, kamusal özelliği ile sağlık hizmeti sunan birimler olarak tanımlanmaktadır (İyi Eczacılık Uygulamaları Kılavuzu, md. 4/m; Sosyal Güvenlik Kurumu Sağlık Uygulama Tebliği, 2013, md. 1.4.1/c). Ayrıca Tanker (1984, s. 79) tarafından serbest eczaneler hastaya en yakın kuruluşlar olarak tanımlanmıştır. Serbest eczacilara sıra beklemeden ve herhangi bir maliyete katlanmadan daha hızlı ulaşılabiliyor olunması, cumartesi yarım gün olsa dahi hizmet sunulması bu tanımı haklı göstermektedir denilebilir.

Serbest eczacılar, sağlık kuruluşları bağlamında sayıca fazla olmaları, halkla iç içe ve kolay ulaşılabilir olmaları, mesleki uzmanlıkları ile hastalara sağlık hizmeti sunabilecek yetiye sahiptirler. Bu özellikleri ile eczacılar, topluma en yakın sağlık danışmanları ve ayrıca sağlık sisteminin hem ilk durağı hem de son durağı diğer bir deyişle sağlık sisteminin giriş çıkış kapıları olarak tanımlanmaktadırlar (Güngör, 2015, s. 22, 74, 85; Üney, 2016, s. 102). Eczanelerin ilk durak olmaları hekime veya tedaviye doğru yönlendirmede önemliyken; son durak olmaları ise ilaç uyuncunun sağlanması, ilaç ve tedaviye dair her türlü bilgiyi sunmaları, sağlıklı yaşam adına öneri ve tavsiyelerde bulunabilmeleri açısından önemlidir.

\subsection{Eczacilık Hizmetlerinden Hasta Memnuniyeti}

Memnuniyet, müşterinin bakış açısından almış olduğu hizmete ve hizmet aldığ işletmeye dair değerlendirmeleri olarak ifade edilmektedir (Oliver, 1997, s. 8). Müşteri merkezli çalışma anlayışında, ayakta kalmanın şartlarından biri müşterilerin beklentileri ile algılamaları arasında dengeyi sağlamak, müşterilerin isteklerini, ihtiyaçlarını, beklentilerini karşılamak ve algılarında olumlu yer edinmektir (Sevim vd., 2008, s. 25). Müşterisi hasta olan sağlık kuruluşları için de başarı ve sürdürülebilirliğinin sağlanmasının koşullarından biri hasta ve yakınlarının beklenti ve ihtiyaçlarının karşılanmasıdır. Bu sebeple sağlık hizmeti sunan kurumlar için hasta ve 
yakınlarının beklentileri ölçüsünde veya üzerinde memnuniyetlerinin sağlanması önemli bir faaliyettir (Tengilimoğlu, 2001, s. 32, 34).

Hasta memnuniyeti, hastaların şikayetlerinin giderilmesi, hizmetten bekledikleri performans1, hizmetin sunuluşunu, sosyo-kültürel değerlerine (kültürüne, alışkanlıklarına, yaşam tarzına, inancina, sosyal sınıf ve statüsüne) uygunluğunu içeren çok değişkenli bir fonksiyon olarak tanımlanmaktadır (Engiz, 1997, s. 64). Sağlık kurumlarının temel çıktısı olarak kabul edilen hasta memnuniyeti, sunulan hizmetin kalitesini değerlendirmede kullanılmakta ve sunulan sağlık hizmetinin kalitesini yansıtan temel ölçütlerden birisidir (Carr-hill, 1992, s. 238; Özkan Aydın vd., 2011, s. 213; Ghose ve Adhish, 2011, s. 241; Kavuncubaş1 ve Yıldırım, 2012, s. 493).

Günümüz tüketicisi sağlık kurumlarından teşhis ve tedavi gibi medikal hizmetlerin yanı sıra bu hizmetleri zenginleştirecek ve katma değerini arttıracak hizmetleri de beklemektedir (Güllülü vd., 2008, s. 2). Bu sebeple sağlık kurumları hastaların medikal ihtiyaçlarını en üst kalite ile karşılamanın yanı sıra estetik, duygusal ihtiyaç ve çeşitli beklentilerine de cevap verebilir durumda olmalıdırlar (Engiz, 1997, s. 67). Bu şekilde tam bir memnuniyet sağlanması başarılabilir.

Sağlık kurum ve kuruluşları, hasta memnuniyetini sağlamak adına hastaya durumu hakkında yeterli ve aydınlatıcı bilgi vermeli, tedavi sürecinde yapması gerekenler hakkında hastay1 bilgilendirilip yönlendirilmeli ve müşterilerinin memnun olarak ayrılmalarını sağlamalıdırlar (Pakdil, 2011; Akt. Atilla, 2012, s. 48). Sağlık hizmeti sunumunun bir paydaşı olan eczanelerde de hasta memnuniyetinin tanımı, amacı ve önemi diğer sağlık kuruluşlarından farklı değildir.

Eczac1lık hizmetlerinden memnuniyet, bireylerin eczanede geçirdikleri zaman diliminde gördükleri muamele, eczanenin fiziki şartları, reçetenin karşılanma hızı, güler yüzlü hizmet, eczacının veya diğer çalışanların ilgisi, eczacının hastayı ilacı ve sağlığı konusunda bilgilendirmesi ve hastanın ilaçları hakkındaki tüm endişelerini giderme çabası gibi birçok faktörü içinde barındıran beklentilerinin karşılanma düzeyi olarak tanımlanabilir.

Sağlık hizmeti sunan kurumların hizmet kalitesinin çıktısı ve göstergesi olan "hasta memnuniyeti" çalışmaları, hastaların sürece ilişkin beklenti ve beklentilerinin karşılanma derecesini içermesi, kurumu değerlendirmesi ve iyileştirmesi nedeniyle önemli olarak görülmektedir (Sitzia ve Wood, 1997, s. 1840). Bu sebeple diğer sağlık kurumları gibi eczacılar da kuruluşlarının hizmet kalitesine dair bir çıktı olarak eczacılık hizmetlerinden memnuniyet çalışmalarını önemsemelidirler.

Sağlık hizmeti sunmanın yanında ticari bir yapıdaki eczanelerin, hizmet sundukları hastaların tekrar kendilerine gelmelerini sağlayabilmek ve böylece rekabetçi sağlık piyasasında ayakta kalabilmek için gelen müşterilerin memnun etmeleri gerekmektedir. Eczacılar iletişimleri, güler yüzleri ve sundukları eczacılık hizmetleri ile hasta memnuniyetini yakalayıp rekabetçi sağlık piyasasında başarılı olabilirler.

Eczaneler ticari işletmeler olmakla birlikte hizmet ürününün sağlık ve ilaç olması sebebiyle sağlık otoritelerince çeşitli düzenlemeler altındadır. Reklam yapamayan eczacılar, hasta memnuniyetini sağlayarak pazarlama faaliyetini gerçekleştirebilirler. Böylece müşteri sadakatini oluşturabilir ve memnun olan hastaların çevrelerine memnuniyetlerini aktarması ile pazarlama sağlayabilirler.

Eczacılık hizmetlerinden memnuniyetin sağlanmasının bir diğer amacı ilaç tedavisinde oluşturabilecek katma değerdir. Tedavisi başarıyla sonuçlanan bireylerin sağlık hizmetlerinden memnuniyet düzeyleri artmaktadır. Ancak bu sürece tersten bakıldığında sağlanan hasta memnuniyeti de başarılı bir ilaç tedavisinin elde edilmesi için önemli bir faktör olmaktadır. Memnun kalan hastaların tedaviye ve rehabilitasyona katılımları artmakta, tedaviye tam uyum sağlamaktadırlar. Böylece hastalığın tedavisinde başarılı sonuçların ortaya çıkma olasılığı artmaktadır (Ross vd., 1987, s. 16). Özellikle ayaktan tedavi gören hastalarda tedavi sürecine 
geçilmeden önceki son durak olan eczaneler, ilaç tedavisinin hem seyrini belirlemede hem de başarı ile sonuçlanmasında önemli bir katkı sağlayabilir.

Eczacılık hizmetlerinde hasta memnuniyeti için reçetenin karşılanması şekli memnuniyeti etkileyebilirken eczacıların değişen rolleri bağlamında özellikle danışmanlık yapmaları, hastalarla iletişim kurmaları, bireylerin hastalıkları ve tedavileri hakkında bilgi sahibi olup gerekli yönlendirmeleri yapmaları hastaların eczacılık hizmetlerine ilişkin algı ve memnuniyetlerini etkileyen faktörler arasında sayılabilir. $\mathrm{Bu}$ varsayımdan yola çıkarak çalışmanın araştırma problemi kurgulanmıştır.

\section{Yöntem}

Sağlık hizmet sunumunda önemli bir paydaş olan serbest eczaneler, sağlık hizmeti sunum zincirinde bireyleri doğru tedaviye yönlendirme ve sonrasında başarılı bir tedavi sürecini sürdürme noktalarında etkin roller üstlenebilecek kurumlardır. Eczacıların değişen rolleri ile geldikleri bu konumu değerlendirebilecek ve kalitesini ortaya koyabilecek faktör, hizmetten yararlanan bireylerin kendileridir. Bu çalışma ile Isparta il merkezinde ikamet eden bireylerin eczacılık hizmetlerine ilişkin algılarının ve eczacılık hizmetlerinden memnuniyet düzeylerinin tespit edilmesi amaçlanmıştır. Sağlık sistemleri içerisinde konumlandırılan ve halk sağlı̆̆ açısından kritik bir yerde olan eczacılık hizmetlerinin değerlendirilmesi, serbest eczacılık mesleğinin geleceği ve sağlık politikaları açısından önemli olarak görülmüştür. Aynı zamanda çalışma, serbest eczanelerden alınan hizmetlerin genel olarak değerlendirildiği yeterli çalışmanın mevcut olmamasından ötürü öncül bir nitelik taşımaktadır.

Çalışmanın evrenini, Isparta il merkezinde yaşayan 18 yaşından büyük tüm bireyler oluşturmaktadır. TÜİK verilerine göre 2017 y1lı Isparta merkez nüfusu 251.531 kişiden oluşmaktadır (TÜIK, 2017). Bir araştırmada örneklemin ne kadar olması konusunda kesin bir sayı vermenin mümkün olmadığ 1 bilinmektedir. Fakat evrenin belli olduğu durumlarda \%95 güven aralığı \%5 hata payı (Dişçi, 2008) olarak alındığında mevcut evrende 18 yaşından büyük 384 kişiye ulaşılması yeterli görülmektedir. Araştırmada kolayda örnekleme yöntemi kullanılarak 411 katılımciya ulaş1lmıştır.

Araştırmada kullanılan anket formu araştırmacı tarafından geliştirilmiştir. Anketin hazırlanması aşamasında öncelikle ulusal ve uluslararası düzeyde literatür taraması yapılmıştır. Yapılan literatür taraması sonucunda araştırmada kullanılan anket sorularını hazırlanması aşamasında MacKeigan ve Larson (1989), Yeğenoğlu Onaran (1994), Johnson ve arkadaşları (1998), Gourley ve arkadaşları (2001), Kucukarslan ve Schommer (2002), Kassam ve arkadaşları (2012), Sakharkar ve arkadaşları (2015), Hücum (2015), Akpınar (2015), Mináriková ve arkadaşları (2016), Alhomoud ve arkadaşlarının (2016) çalışmalarından yararlanılmıştır. Bu çalışmaların literatür, anket ve ölçeklerinden faydalanılmıştır. Anket sorularının geliştirilmesi aşamasında Sağlik Yönetimi Bölümü akademisyenlerinden ve eczacılardan uzman görüşü alınmıştır. Hazırlanan anket sorularının anlaşılabilirliğini denetlemek amacıyla, kolayda örnekleme yöntemiyle 30 kişilik grup üzerinde pilot çalışma yapılmıştır. Anlaşılmayan ve tekrar eden sorular yeniden düzenlenmiş ve katılımcılara yöneltilen anket meydana getirilmiştir.

Sakharkar ve arkadaşları (2015) tarafindan geliştirilmiş, Hücum (2015) tarafindan Türkçe'ye uyarlanıp geçerlilik güvenilirlik çalışması yapılan "Eczacılık Hizmetleri İle İlgili Hasta Memnuniyeti Anketi (The Patient Satisfaction with Pharmacy Services Questionnaire (PSPSQ 2.0))" isimli ölçekten yararlanılmakla birlikte klinik eczacılık sunan eczanelerden hizmet alan hastaların memnuniyetini ölçmesi sebebiyle aynen kullanılmamıştır.

Anket formları aracılığıyla elde edilen veriler Statistical Package for the Social Sciences (SPSS 24.0) programı kullanılarak analiz edilmiştir. Anketlerde 5'li Likert ölçeğine göre yapılandırılmış ifadelere verilen cevapların değerlendirilmesi yapılırken aralıkların eşit olduğu varsayımında bulunulmaktadır. Bu varsayımdan hareketle aritmetik ortalamalar için puan aralığ “0,80" hesaplanmıştır. Anketteki ifadeler yorumlanırken 1.00-1.79 "Hiçbir Zaman”, 1.80-2.59 
"Nadiren”, 2.60-3.39 “Ara Sıra”, 3.40-4.19 “S1k S1k”, 4.20-5.00 “Her Zaman” şeklindeki kategori kullanılmıştır (Kaplanoğlu, 2014, s. 138).

Araştırmacı tarafindan elde edilen veriler öncelikle faktör analizine tabii tutulmuştur. Güvenilirliği düşüren ve teorik çerçeveye uymayan sorular faktör analizi aşamasında analizden çıkartılmıştır. Faktör analizi yapılırken Varimax döndürme işlemi yapılımıştır. Analiz sonuncunda soruların 3 boyutta toplandığ 1 tespit edilmiştir. Anketten elde edilen veriler aritmetik ortalama, standart sapma, frekans ve yüzde hesaplamaları ile analiz edilmiş ve istatistiksel değerlendirmeler bu puan ortalamaları üzerinden yapılmıştır. Verilerin normal dağılıma uygun olup olmadığını tespit etmek için her bir boyutun çarpıklık ve basıklık değerleri hesaplanmıştır.

Araştırmalar sonucunda elde edilen veri setinin normal dağılım sergileyip sergilemediğini yorumlayabilmek için basıklık ve çarpıklık katsayılarının -2 ile +2 arasında bir değer alması gerekmektedir (Kan, 2016: 116). Yapılan bu çalışmada basıklık ve çarpıklık katsayılarının -2 ile +2 arasında değerlerler aldığı tespit edildiğinden verilerin analizinde parametrik testler kullanılmıştır. Parametrik testlerden ikili grupların karşılaştırılmasında "T-testi"; üç ve üzeri grupların karşılaştırılmasında "Anova (varyans analizi) testi" kullanılmıştır. Anavo analizi sonucunda gruplar arasında fark bulunduğunda, farkın kaynağını "Tukey's-b testi" ile tespit edilmiştir.

\section{Bulgular}

Çalışmaya katılan bireylerin demografik değişkenlere göre dağılımı Tablo 1'de gösterilmektedir.

Tablo 1. Katılımcıların demografik değişkenlere göre dağılımı

\begin{tabular}{|c|c|c|}
\hline Değişkenler & Frekans & Yüzde \\
\hline \multicolumn{3}{|c|}{ Cinsiyet } \\
\hline Erkek & 186 & 45,5 \\
\hline Kadın & 223 & 54,5 \\
\hline \multicolumn{3}{|c|}{ Yaş (Yll) } \\
\hline $19-24$ & 85 & 22,0 \\
\hline $25-34$ & 121 & 31,4 \\
\hline $35-44$ & 81 & 21,0 \\
\hline $45+$ & 99 & 25,6 \\
\hline \multicolumn{3}{|c|}{ Medeni Durum } \\
\hline Evli & 248 & 60,9 \\
\hline Bekâr & 155 & 38,1 \\
\hline Diğger & 4 & 1,0 \\
\hline \multicolumn{3}{|c|}{ Eğitim Durumu } \\
\hline İlköğretim & 80 & 19,6 \\
\hline Lise & 67 & 16,4 \\
\hline Ön Lisans & 38 & 9,3 \\
\hline Lisans & 169 & 41,4 \\
\hline Lisansüstü & 54 & 13,2 \\
\hline \multicolumn{3}{|c|}{ Aylık Gelir (TL) } \\
\hline-1603 & 56 & 16,5 \\
\hline $1604-3500$ & 133 & 39,2 \\
\hline $3501-5500$ & 83 & 24,5 \\
\hline $5501-$ & 67 & 19,8 \\
\hline \multicolumn{3}{|c|}{ Çalışma Durumu } \\
\hline Kamu Sektörü & 117 & 28,7 \\
\hline Özel Sektör & 118 & 29,0 \\
\hline Diğger & 172 & 42,3 \\
\hline
\end{tabular}

Tablo 1'de görüldüğü üzere, katılımcıların \%45,5'i erkek iken \%54,5'i kadınlardan oluşmaktadır. Araştırmaya katılan bireylerin \%22'si 19-24 yaş aralığında, \%31,4'ü 25-34 yaş aralığında, \%21,0'ı 35-44 yaş aralığında ve \%25,6'sı 45 yaş ve üzerinde olduğu görülmektedir. 
Katılımcıların büyük çoğunluğunun $(\% 60,9)$ evli olduğu tespit edilmiştir. Katılımcıların eğitim durumlarına bakıldığında çoğunluğunun $(41,4)$ lisans eğitimine sahip olduğu görülmektedir.

Araştırmaya katılan bireylerin aylık gelir durumuna bakıldığında \%39,2'sinin 1604-3500 TL aralığında olduğu ortaya çıkmıştır. Son olarak katılımcıların çalışma durumu incelendiğinde \%28 7'sinin kamu sektöründe, \%29'unun özel sektörde çalıştığı tespit edilmiştir. Katılımcıların \%42,3'ü ise diğer kategorisinden emekli, öğrenci, ev hanımı, işsiz olarak çalışma durumlarını belirtmiş̧lerdir.

Tablo 2. Katılımcıların eczacılık hizmetlerinden memnuniyet ile ilgili ifadelerden aldıkları puanların dağılımı

\begin{tabular}{|c|c|c|c|}
\hline No & İfadeler & $\bar{X}$ & SS \\
\hline 1 & İlaç aldığım eczacı sağlık sorunlarım/kaygılarım ile ilgilenir. & 2,929 & 1,425 \\
\hline 2 & İlaç aldığım eczacı, hasta olarak sorularıma cevap vermeye isteklidir. & 3,365 & 1,251 \\
\hline 3 & $\begin{array}{l}\text { İlaç aldığım eczacı hastalara yardımcı olmak için yeteri kadar vakit } \\
\text { ayırır. }\end{array}$ & 3,468 & 1,175 \\
\hline 4 & İlaç aldığım eczacı ilaç uyumunun önemli olduğunu anlatır. & 2,993 & 1,394 \\
\hline 5 & $\begin{array}{l}\text { İlaç aldığım eczacı sağlıklı yaşam konusunda faydalı tavsiyelerde } \\
\text { bulunur. }\end{array}$ & 2,685 & 1,395 \\
\hline 6 & İlaç aldığım eczacı ilaçların yan etkileri hakkında bilgilendirme yapar. & 2,722 & 1,390 \\
\hline 7 & Eczacının muadil ilacı tavsiye etmesini doğru bulurum. & 2,787 & 1,419 \\
\hline 8 & $\begin{array}{l}\text { İlaç aldığım eczacı ilaçlarımı nasıl kullanmam gerektiği konusunda } \\
\text { açıklama yapar. }\end{array}$ & 4,140 & 1,088 \\
\hline 9 & İlaç aldığım eczacı ilgili ve naziktir. & 3,941 & 1,082 \\
\hline 10 & $\begin{array}{l}\text { İlaç aldığım eczacı tedavimin başarılı sonuçlanması için tavsiyelerde } \\
\text { bulunur. }\end{array}$ & 3,025 & 1,325 \\
\hline 11 & İlaç aldığım eczacı ile iletişim kurarken kendimi rahat hissederim. & 3,791 & 1,242 \\
\hline 12 & Eczacımdan sağlık konularında istediğim bilgileri alabilirim. & 3,413 & 1,228 \\
\hline 13 & İlaç aldığım eczaneden genel olarak memnunum. & 3,885 & 1,118 \\
\hline 14 & Gerek duyduğumda sağlık ihtiyaçlarım için eczacıya danışırım. & 3,186 & 1,402 \\
\hline 15 & $\begin{array}{l}\text { İlaç aldığım eczacı ilaçların ne için kullanacağım konusunda açıklama } \\
\text { yapar. }\end{array}$ & 3,556 & 1,301 \\
\hline 16 & İlaçların hazırlanması için uzun bir süre bekletilirim. & 2,528 & 1,170 \\
\hline 17 & Eczane çalışanları nazik ve saygılıdırlar. & 4,012 & 1,033 \\
\hline 18 & $\begin{array}{l}\text { İlaç aldığım eczacı, bilgilendirme yapmadan reçetedeki ilaçların } \\
\text { muadilini verir. }\end{array}$ & 2,391 & 1,312 \\
\hline 19 & Eczaneden ayrıldığımda ilacı nasıl kullanacağımı öğrenmiş olurum. & 4,047 & 1,064 \\
\hline 20 & İlaç aldığım eczacı sağlığım ile ilgili danışmanlık yapar. & 2,731 & 1,322 \\
\hline 21 & İlaç aldığım eczacı soru sormam için uygun firsatları oluşturur. & 3,097 & 1,279 \\
\hline 22 & $\begin{array}{l}\text { İlaç aldığım eczacı sağlığımı geliştirmek veya sağlıklı kalmam için } \\
\text { çabalar. }\end{array}$ & 2,814 & 1,404 \\
\hline 23 & $\begin{array}{l}\text { İlaç aldığım eczacı, ilaçları kullanmam konusunda güvende hissetmemi } \\
\text { sağlar. }\end{array}$ & 3,294 & 1,315 \\
\hline 24 & Eczaneden ayrıldığımda ilacı nerede muhafaza edeceğimi bilirim. & 3,647 & 1,335 \\
\hline 25 & İlaç aldığım eczacı, açık anlaşııı bir şekilde konuşur. & 3,941 & 1,137 \\
\hline
\end{tabular}




\begin{tabular}{|clcc|}
\hline $\mathbf{2 6}$ & $\begin{array}{l}\text { İlaç aldığım eczacı, ilaç tedavimi değerlendirmek için önceki sağlık } \\
\text { durumum ve ilaçlarım hakkında bilgi ister. }\end{array}$ & 2,601 & 1,382 \\
\hline $\mathbf{2 7}$ & Eczaneden memnun ayrılmazsam eczanemi değiştiririm. & 3,896 & 1,347 \\
\hline $\mathbf{2 8}$ & $\begin{array}{l}\text { İlaç aldığım eczacı ilaçlarımın faydalı olup olmadığı ile ilgili benden } \\
\text { geri dönüş alır. }\end{array}$ & 2,110 & 1,310 \\
\hline $\mathbf{2 9}$ & Verdiği bilgiler konusunda eczacıya güvenirim. & 3,650 & 1,129 \\
\hline $\mathbf{3 0}$ & $\begin{array}{l}\text { İlaç aldığım eczacı, muadil ilaçları kullanıp kullanamayacağım } \\
\text { konusunda tavsiyelerde bulunması beni memnun eder. }\end{array}$ & 3,646 & 1,293 \\
\hline $\mathbf{3 1}$ & $\begin{array}{l}\text { İlaç aldığım eczacı, eczaneye her gittiğimde beni samimi bir şekilde } \\
\text { karşılar. }\end{array}$ & 3,775 & 1,205 \\
\hline $\mathbf{3 2}$ & İlaç aldığım eczacı tüm bilgileri anlayıp anlamadığımı kontrol eder. & 2,855 & 1,379 \\
\hline $\mathbf{3 3}$ & $\begin{array}{l}\text { İlaç aldığım eczanenin fiziki ortamından (ferahlık, genişlik vb.) } \\
\text { memnunum. }\end{array}$ & 3,879 & 1,097 \\
\hline $\mathbf{3 4}$ & İlaç aldığım eczanenin temizliğinden memnunum. & 4,173 & 0,980 \\
\hline $\mathbf{3 5}$ & $\begin{array}{l}\text { İlaç aldığım eczanenin hastalar için bekleme yerlerinin bulunmasından } \\
\text { memnunum. }\end{array}$ & 4,074 & 1,067 \\
\hline $\mathbf{3 6}$ & İlaç aldığım eczaneyi başkalarına tavsiye ederim. & 3,625 & 1,346 \\
\hline
\end{tabular}

Ankette yer alan her bir ifadenin aritmetik ortalamasına ve standart sapma dağılımlarına Tablo 2'de yer verilmiştir. Tabloya bakıldığında katılımcıların, eczacının ilaçların nasıl kullanılması gerektiği konusunda açıklama yapması $(4,140 \pm 1,088)$, eczacının $(3,941 \pm 1,082)$ ve eczane çalışanlarının nazik ve saygılı olmaları $(4,012 \pm 1,033)$, eczaneden ayrıldıklarında ilacı nasıl kullanacaklarını öğrenmiş olmaları $(4,047 \pm 1,064)$ noktalarında memnuniyet düzeylerinin yüksek olduğu görülmektedir. Ayrıca katılımcılar ilaç aldıkları eczaneden genel olarak memnun $(3,885 \pm 1,118)$ olduklarını belirtmişlerdir.

Anket ifadelerine katılım düzeylerinden katılımcıların ilaç tedavisinde ilaç uyumunun önemini anlatma $(2,993 \pm 1,394)$, ilacın yan etkilerini söyleme $(2,722 \pm 1,390)$, ilacın ne için kullanıldığını açıklama $(3,556 \pm 1,301)$ ve ilaçları kullanırken ilaca karşı güven duyulmasını sağlama $(3,294 \pm 1,315)$ noktalarında eczacılık hizmetlerinden orta derecede memnuniyet duyduğu görülmektedir. Ayrıca katılımcılar tarafından eczacıların sağlıklı yaşam konularında tavsiyede bulunmaları $(2,685 \pm 1,395)$ ve sağlık danışmanlığı yapmaları $(2,731 \pm 1,322)$ değerlendirildiğinde orta derecede memnuniyet duydukları tespit edilmiştir.

Anketin ifadeleri arasında "İlaç aldığım eczanenin temizliğinden memnunum." $(4,173 \pm$ 0,980) ifadesi katılım düzeyi en yüksek ifadeyken, "İlaç aldığım eczacı ilaçlarımın faydalı olup olmadığ ile ilgili benden geri dönüş alır." $(2,110 \pm 1,310)$ ifadesi katılımcılar tarafından katılım düzeyi en düşük olan ifade olarak görülmektedir.

Tablo 3. Eczacilık hizmetlerinin değerlendirilmesine ilişkin faktör analizi

\begin{tabular}{|c|c|c|c|}
\hline & Faktörler & $\begin{array}{l}\text { Faktör } \\
\text { Yükleri }\end{array}$ & $\begin{array}{c}\text { Açıklanan } \\
\text { Varyans }\end{array}$ \\
\hline \multicolumn{4}{|c|}{ 1.Faktör: Danışmanlık Rolü } \\
\hline & $\begin{array}{l}\text { İlaç aldığım eczacı sağlığımı geliştirmek veya sağlıklı kalmam için } \\
\text { çabalar. }\end{array}$ & 0,805 & \multirow{5}{*}{44,738} \\
\hline \multirow[t]{2}{*}{20} & \multirow{4}{*}{$\begin{array}{l}\text { İlaç aldığım eczacı sağlığım ile ilgili danışmanlık yapar. } \\
\text { İlaç aldığım eczacı sağlıklı yaşam konusunda faydalı tavsiyelerde } \\
\text { bulunur. } \\
\text { İlaç aldığım eczacı, ilaç tedavimi değerlendirmek için önceki sağlık } \\
\text { durumum ve ilaçlarım hakkında bilgi ister. } \\
\text { İlaç aldığım eczacı ilaçlarımın faydalı olup olmadığı ile ilgili benden geri } \\
\text { dönüs alır. }\end{array}$} & 0,800 & \\
\hline & & 0,781 & \\
\hline & & 0,766 & \\
\hline & & 0,699 & \\
\hline
\end{tabular}


10 İlaç aldığım eczacı tedavimin başarılı sonuçlanması için tavsiyelerde bulunur.

1 İlaç aldığım eczacı sağ lık sorunlarım/kaygılarım ile ilgilenir.

21 İlaç aldığım eczacı soru sormam için uygun firsatları oluşturur.

6 İlaç aldığım eczacı ilaçların yan etkileri hakkında bilgilendirme yapar.

23 İlaç aldığım eczacı, ilaçları kullanmam konusunda güvende hissetmemi sağlar.

4 İlaç aldığım eczacı ilaç uyumunun önemli olduğunu anlatır.

12 Eczacımdan sağlık konularında istediğim bilgileri alabilirim.

32 İlaç aldığım eczacı tüm bilgileri anlayıp anlamadığımı kontrol eder.

15 İlaç aldığım eczacı ilaçların ne için kullanacağım konusunda açıklama yapar.

14 Gerek duyduğumda sağlık ihtiyaçlarım için eczacıya danışırım.

\begin{tabular}{|c|}
\hline 0,698 \\
\hline 0,693 \\
\hline 0,687 \\
\hline 0,680 \\
\hline 0,667 \\
\hline 0,664 \\
\hline 0,631 \\
\hline 0,629 \\
\hline 0,568 \\
\hline 0,564 \\
\hline
\end{tabular}

\section{Faktör: Fiziki Şartlar ve İletişim}

33 İlaç aldığım eczanenin fiziki ortamından (ferahlık, genişlik vb.) memnunum.

34 İlaç aldığım eczanenin temizliğinden memnunum.

35 İlaç aldığım eczanenin hastalar için bekleme yerlerinin bulunmasından memnunum.

31 İlaç aldığım eczacı, eczaneye her gittiğimde beni samimi bir şekilde

31 karşılar.

29 Verdiği bilgiler konusunda eczacıya güvenirim.

25 İlaç aldığım eczacı, açık anlaşııır bir şekilde konuşur.

\begin{tabular}{|c|}
\hline 0,849 \\
\hline 0,812 \\
\hline 0,798 \\
\hline 0,680 \\
\hline 0,621 \\
\hline 0,543 \\
\hline
\end{tabular}

\section{Faktör: İlaç Kullanımı Bilgilendirme}

8 İlaç aldığım eczacı ilaçlarımı nasıl kullanmam gerektiği konusunda açıklama yapar.

\begin{tabular}{|c|}
0,821 \\
\hline 0,720
\end{tabular}

Tablo 3'te eczac1lık hizmetlerinin değerlendirilmesi anketinin 3 boyutunun faktör yükleri verilmiştir. Örneklem büyüklüğü yeterliliği, verilen faktör analizine uygunluğu ve değişkenler arasındaki korelasyonun anlamlılığı için KMO (Kaiser-Meyer-Olkin) değerine bakılmış ve Barlett testi yapılmıştır. Test sonucunda KMO değeri 0,954 bulunmuştur. Bulunan değer örneklem büyüklüğünün analiz için yeterli olduğunu göstermektedir. Barlett testi sonucunda değişkenler arası korelasyonun $\mathrm{p}<0.00$ düzeyinde anlamlı olduğu anlaşılmıştır. Eczacılık hizmetlerini değerlendirme anketi verilerine yapılan faktör analizi sonucunda Danışmanlık Rolü, Fiziki Şartlar ve İletişim, İlaç Kullanımı Bilgilendirme olmak üzere 3 faktöre ayrılmıştır. Bu faktörler, varyansın toplam \%60,863'ünü açıklamaktadır. 
Tablo 4. Boyutlarının psikometrik özellikleri

\begin{tabular}{|l|c|c|c|c|c|c|c|}
\hline \multicolumn{1}{|c|}{ Boyutlar } & $\begin{array}{c}\text { Ifade } \\
\text { Sayısı }\end{array}$ & $\begin{array}{c}\text { Max- } \\
\text { Min }\end{array}$ & $\begin{array}{c}\text { Cronbach } \\
\text { Alfa }\end{array}$ & $\bar{X}$ & SS & $\begin{array}{c}\text { Kurtotis } \\
\text { (Basıklık) }\end{array}$ & $\begin{array}{c}\text { Skewness } \\
\text { (Çarpıklı) }\end{array}$ \\
\hline $\begin{array}{l}\text { Danışmanlık } \\
\text { Rolü Boyutu }\end{array}$ & 15 & $1-5$ & 0,936 & 2,928 & 0,984 & $-0,814$ & 0,149 \\
\hline $\begin{array}{l}\text { Fiziki Sartlar } \\
\text { ve İletişim } \\
\text { Boyutu }\end{array}$ & 6 & $1-5$ & 0,871 & 3,929 & 0,855 & $-0,274$ & $-0,631$ \\
\hline $\begin{array}{l}\text { İlaç Kullanımı } \\
\text { Bilgilendirme } \\
\text { Boyutu }\end{array}$ & 2 & $1-5$ & 0,710 & 4,092 & 0,949 & 0,580 & $-1,060$ \\
\hline
\end{tabular}

Tablo 4'te ise boyutların psikometrik özelliklerine ilişkin bilgiler yer almaktadır. Araştırmada bireylerin eczacılık hizmetlerine ilişkin memnuniyet değerlendirmeleri faktör analizi sonucu 3 boyut çerçevesinde değerlendirilmiş ve her bir boyutun aldığı değerler tabloda gösterilmiştir.

Danışmanlık Rolü Boyutu: Bu boyut 15 ifadeden oluşmaktadır. Bu boyuttaki ifadeler ile katılımcılardan, eczacıların klasik ilaç verme işlemleri dışında ilgi düzeyleri, ilaç ve sağlık konularında tavsiye vermeleri, hastalarına danışmanlık yapmaları gibi konularda değerlendirme alınmıştır. Danışmanlık Rolü Boyutunun aritmetik ortalaması 2,928 ve standart sapması 0,984 olarak bulunmuştur. Boyutun güvenilirlik derecesi (Cronbach Alpha) ise 0,962 olarak bulunmuştur. Bu boyut yüksek derecede güvenilir bulunmuştur.

Fiziki Şartlar ve İletişim Boyutu: Bu boyutta 6 ifade yer almaktadır. Bu boyut altında hem iletişime dair ifadeler hem de eczanenin fiziki şartlarından memnuniyete dair ifadeler toplanmıştır. Fiziki Şartlar ve İletişim Boyutunun aritmetik ortalaması 3,929 ve standart sapması 0,855 olarak bulunmuştur. Boyutun güvenilirlik derecesi (Cronbach Alpha) ise 0,871 olarak yüksek güvenilir bulunmuştur.

İlaç Kullanımı Bilgilendirme Boyutu: Bu boyut ilaç kullanımı hakkında bilgi sahibi olmayı içeren 2 ifadeden oluşmaktadır. İlaç Kullanımı Bilgilendirme Boyutunun aritmetik ortalaması 4,092 ve standart sapması 0,949 olarak bulunmuştur. Boyutun güvenilirlik derecesi (Cronbach Alpha) ise 0,710 olarak güvenilir bulunmuştur.

Eczacilık hizmetlerinden memnuniyeti ölçen ankette yer alan boyutlar demografik değişkenler ile sürekli aynı eczaneye gitme, kronik hastalığa sahip olma ve eczane algısı ile karşılaştırılmıştır. Danışmanlık Rolü Boyutunun aldığı puanların demografik değişkenlere göre dağılımı Tablo 5'te verilmiştir.

Tablo 5. Danışmanlık rolü boyutunun demografik değişkenlere göre karş1laștırması

\begin{tabular}{|c|c|c|c|c|}
\hline Değişkenler & $\mathbf{N}$ & $\bar{X}$ & SS & Test Değerleri \\
\hline \multicolumn{5}{|l|}{ Cinsiyet } \\
\hline Erkek & 162 & 2,955 & 1,003 & \multirow{2}{*}{$\begin{array}{l}\mathrm{t}=0,460 \\
\mathrm{p}=0,646\end{array}$} \\
\hline Kadın & 201 & 2,907 & 0,972 & \\
\hline \multicolumn{5}{|l|}{ Yaş (Yıl) } \\
\hline-24 & 76 & 2,749 & 0,887 & \multirow{4}{*}{$\begin{array}{l}F=4,261 \\
\mathbf{p}=\mathbf{0 , 0 0 6}\end{array}$} \\
\hline $25-34$ & 111 & 2,786 & 0,985 & \\
\hline $35-44$ & 69 & 3,019 & 1,095 & \\
\hline $45+$ & 88 & 3,214 & 0,984 & \\
\hline \multicolumn{5}{|l|}{ Medeni Durum } \\
\hline Evli & 218 & 3,038 & 0,995 & \multirow{2}{*}{$\begin{array}{l}\mathrm{t}=2,491 \\
\mathbf{p}=\mathbf{0 , 0 1 3}\end{array}$} \\
\hline Bekâr & 141 & 2,778 & 0,948 & \\
\hline \multicolumn{5}{|l|}{ Eğitim Durumu } \\
\hline İlköğretim & 62 & 3,136 & 1,008 & \multirow{2}{*}{$\begin{array}{c}F=4,251 \\
\mathbf{p}=\mathbf{0 , 0 0 2}\end{array}$} \\
\hline Lise & 62 & 3,056 & 1,063 & \\
\hline
\end{tabular}




\begin{tabular}{|c|c|c|c|c|}
\hline Ön Lisans & 33 & 3,186 & 1,010 & \\
\hline Lisans & 154 & 2,889 & 0,935 & \\
\hline Lisansüstü & 51 & 2,489 & 0,865 & \\
\hline \multicolumn{5}{|l|}{ Aylık Gelir (TL) } \\
\hline-1603 & 48 & 2,843 & 1,048 & \multirow{4}{*}{$\begin{array}{l}F=0,263 \\
p=0,852\end{array}$} \\
\hline $1604-3500$ & 114 & 2,980 & 0,968 & \\
\hline $3501-5500$ & 80 & 2,894 & 0,936 & \\
\hline $5501-$ & 61 & 2,919 & 1,055 & \\
\hline \multicolumn{5}{|l|}{ Çalıșma Durumu } \\
\hline Kamu Sektörü & 110 & 2,998 & 0,985 & \multirow{3}{*}{$\begin{array}{l}F=2,400 \\
p=0,092\end{array}$} \\
\hline Özel Sektör & 100 & 3,051 & 1,051 & \\
\hline Diğer & 151 & 2,797 & 0,937 & \\
\hline \multicolumn{5}{|c|}{ Sürekli Aynı Eczaneye Gitme } \\
\hline Evet & 213 & 3,300 & 0,904 & \multirow{2}{*}{$\begin{array}{l}\mathrm{t}=9,482 \\
\mathbf{p}=\mathbf{0 , 0 0 0}\end{array}$} \\
\hline Hayır & 148 & 2,405 & 0,851 & \\
\hline \multicolumn{5}{|l|}{ Kronik Hastalık } \\
\hline Evet & 72 & 3,032 & 1,054 & \multirow{2}{*}{$\begin{array}{l}\mathrm{t}=1,017 \\
\mathrm{p}=0,310\end{array}$} \\
\hline Hayır & 289 & 2,900 & 0,966 & \\
\hline \multicolumn{5}{|l|}{ Eczane Algısı } \\
\hline Sağlik Kuruluşu & 66 & 0,855 & 0,047 & \multirow{3}{*}{$\begin{array}{r}\mathrm{F}=16,132 \\
\mathbf{p}=\mathbf{0 , 0 0 0}\end{array}$} \\
\hline Ticarethane & 58 & 0,861 & 0,105 & \\
\hline İlaç Alınan Yer & 235 & 0,968 & 0,113 & \\
\hline
\end{tabular}

Danışmanlık rolü boyutunun puanları katılımcıların yaşlarına göre karşılaştırıldığında, bireylerin yaşları arttıkça danışmanlık rolünden aldıkları puanlar da artış eğilimi göstermiş ve gruplar arasında istatistiksel olarak anlamlı bir farkl1lık olduğu tespit edilmiştir $(F=4,261$, $\mathrm{p}=0,006)$. Yapılan Tukey's-b testi sonucunda farkın 45 yaş ve üzeri bireylerin danışmanlık boyutundan aldıkları puanların, 34 ve altı yaştaki bireylere göre daha yüksek olmasından kaynaklandığı anlaşılmıştır. Yaşlı bireylerde, eczacıların danışmalık rolü üstlendiklerine dair algı daha yüksek bulunmuştur.

Ayrıca danışmanlık rolü boyutu puanlarının katılımcıların medeni durumuna göre karşılaştırıldığında istatistiksel olarak anlamlı bir fark olduğu bulunmuştur $(t=2,491, p=0,013)$. Evli bireylerin bekâr bireylere göre puanlarının yüksek olduğu görülmüştür. Bu nedenle evli bireylerde eczacının danışmanlık hizmetlerine ilişkin algı düzeylerinin daha yüksek olduğu söylenebilir.

Danışmanlık rolü boyutu puanları katılımcıların eğitim durumuna göre karşılaştırıldığında da istatistiksel olarak anlamlı bir fark olduğu ortaya çıkmıştır $(\mathrm{F}=4,251$, $\mathrm{p}=0,002$ ). Yapılan Tukey's-b testi sonucunda farklılı̆̆ın, eğitim düzeyi yüksek olan (lisans ve lisansüstü eğitim) bireylerin puanlarının, diğer gruplara göre daha düşük olmasından kaynaklandığı tespit edilmiştir. Katılımcılar arasında eğitim düzeyi yüksek olan bireylerde, eczacıların danışmalık rolü üstlendiklerine dair algı düzeyinin daha düşük olduğu tespit edilmiştir.

Danışmanlık rolü boyutunun puanları sürekli aynı eczane gitme durumuna göre karşılaştırıldığında, istatistiksel olarak anlamlı bir fark olduğu tespit edilmiştir $(\mathrm{t}=9,482, \mathrm{p}=$ 0,000). Sürekli aynı eczaneye giden katılımcıların, eczacının danışmanlık rolünü yerine getirdiğine dair algısı daha yüksek olduğu ortaya çıkmıştır.

Son olarak danışmanlık rolü boyutunun puanları bireylerin eczaneyi nasıl bir yer olarak algıladığı durumu ile karşılaştırıldığında istatistiksel olarak anlamlı bir fark olduğu görülmüştür $(\mathrm{F}=16,132, \mathrm{p}=0,000)$. Yapılan Tukey's-b testi sonucunda farkın, üç grubun birbirinden farklı olmasından kaynaklandığı anlaşılmıştır. Eczaneyi ilaç alınan yer olarak görenlerin danışmanlık rolü algısı düzeylerinin en yüksek olduğu, bunu ticarethane olarak görenlerin takip ettiği ve sağlık kuruluşu olarak görenlerin görece olarak algı düzeylerinin en düşük grup olduğu anlaşılmıştır. 
Tablo 6. İlaç kullanımı bilgilendirme boyutunun demografik değişkenlere göre karşılaş̧tırması

\begin{tabular}{|c|c|c|c|c|}
\hline Değişkenler & $\mathbf{N}$ & $\bar{X}$ & SS & Değişkenler \\
\hline \multicolumn{5}{|l|}{ Cinsiyet } \\
\hline Erkek & 182 & 4,159 & 0,996 & \multirow{2}{*}{$\begin{array}{l}\mathrm{t}=1,224 \\
\mathrm{p}=0,222\end{array}$} \\
\hline Kadın & 220 & 4,043 & 0,905 & \\
\hline \multicolumn{5}{|l|}{ Yaş (Yıl) } \\
\hline$-\quad 24$ & 84 & 4,036 & 1,017 & \multirow{4}{*}{$\begin{array}{c}F=6,427 \\
p=0,395\end{array}$} \\
\hline $25-34$ & 119 & 4,088 & 0,887 & \\
\hline $35-44$ & 80 & 4,094 & 1,028 & \\
\hline $45+$ & 96 & 4,260 & 0,871 & \\
\hline \multicolumn{5}{|l|}{ Medeni Durum } \\
\hline Evli & 243 & 4,124 & 0,939 & \multirow{2}{*}{$\begin{array}{l}\mathrm{t}=0,561 \\
\mathrm{p}=0,575\end{array}$} \\
\hline Bekâr & 153 & 4,069 & 0,958 & \\
\hline \multicolumn{5}{|l|}{ Eğitim Durumu } \\
\hline İlköğretim & 76 & 4,132 & 0,932 & \multirow{5}{*}{$\begin{array}{l}\mathrm{F}=0,173 \\
\mathrm{p}=0,952\end{array}$} \\
\hline Lise & 66 & 4,046 & 1,115 & \\
\hline Ön Lisans & 37 & 4,176 & 0,966 & \\
\hline Lisans & 169 & 4,098 & 0,948 & \\
\hline Lisansüstü & 53 & 4,047 & 0,742 & \\
\hline \multicolumn{5}{|l|}{ Aylık Gelir (TL) } \\
\hline-1603 & 55 & 3,964 & 0,985 & \multirow{4}{*}{$\begin{array}{l}F=1,510 \\
p=0,212\end{array}$} \\
\hline $1604-3500$ & 130 & 4,086 & 0,971 & \\
\hline $3501-5500$ & 83 & 3,994 & 0,992 & \\
\hline $5501-$ & 66 & 4,280 & 0,760 & \\
\hline \multicolumn{5}{|l|}{ Çalışma Durumu } \\
\hline Kamu Sektörü & 116 & 4,207 & 0,802 & \multirow{3}{*}{$\begin{array}{l}\mathrm{F}=1,625 \\
\mathrm{p}=0,198\end{array}$} \\
\hline Özel Sektör & 116 & 3,983 & 1,055 & \\
\hline Diğer & 168 & 4,095 & 0,960 & \\
\hline \multicolumn{5}{|c|}{ Sürekli Aynı Eczaneye Gitme } \\
\hline Evet & 234 & 4,301 & 0,857 & \multirow{2}{*}{$\begin{array}{l}t=5,300 \\
\mathbf{p}=\mathbf{0 , 0 0 0}\end{array}$} \\
\hline Hayır & 166 & 3,807 & 1,006 & \\
\hline \multicolumn{5}{|l|}{ Kronik Hastalık } \\
\hline Evet & 77 & 4,173 & 0,819 & \multirow{2}{*}{$\begin{array}{l}t=2,873 \\
\mathbf{p}=\mathbf{0 , 0 0 4}\end{array}$} \\
\hline Hayır & 308 & 3,863 & 0,856 & \\
\hline \multicolumn{5}{|l|}{ Eczane Algısı } \\
\hline Sağllk Kuruluşu & 71 & 4,380 & 0,694 & \multirow{3}{*}{$\begin{array}{l}F=7,158 \\
\mathbf{p}=\mathbf{0 , 0 0 0}\end{array}$} \\
\hline Ticarethane & 68 & 3,683 & 1,122 & \\
\hline İlaç Alınan Yer & 258 & 4,128 & 0,923 & \\
\hline
\end{tabular}

Tablo 6'da görüldüğü üzere eczacıların ilaç kullanımı bilgilendirme boyutunun katılımciların cinsiyetine $(\mathrm{t}=1,224, \mathrm{p}=0,222)$, yaşına $(\mathrm{F}=6,427, \mathrm{p}=0,395)$, medeni durumuna $(\mathrm{t}=0,561, \mathrm{p}=0,575)$, eğitim durumuna $(\mathrm{F}=0,173, \mathrm{p}=0,952)$, ayl1k gelirine $(\mathrm{F}=1,510, \mathrm{p}=0,212)$ ve çalışma durumuna $(\mathrm{F}=1,625, \mathrm{p}=0,198)$ göre karşılaştırıldığında istatistiksel olarak anlamlı bir 
fark bulunmamıştır. Ancak ilaç kullanımı bilgilendirme boyutunun puanları katılımcıların yaşlarına göre karşılaştırıldığında, istatistiksel anlamda fark bulunmamış olmasına rağmen bireylerin yaşları arttıkça ilaç kullanımı bilgilendirme boyutundan aldıkları puanların da artış eğiliminde olduğu görülmektedir.

İlaç kullanımı bilgilendirme boyutunun puanları katılımcıların sürekli aynı eczaneyi kullanma durumuna göre karşılaştırıldığında istatistiksel olarak anlamlı bir fark olduğu ortaya çıkmıştır ( $\mathrm{t}=5,300, \mathrm{p}=0,000)$. Sürekli aynı eczaneye giden bireylerin, eczacının klasik görevi olan ilaç kullanımı bilgilendirmesinden memnuniyet düzeyi farklı eczanelerden hizmet alan bireylerden daha yüksek olduğu tespit edilmiştir.

İlaç kullanımı bilgilendirme boyutunun puanları katılımcıların kronik hastalığı olup olmama durumuna göre karşılaştırıldığında istatistiksel olarak anlamlı bir fark olduğu ortaya çıkmıştır ( $\mathrm{t}=2,873, \mathrm{p}=0,004)$. Kronik hastalığı olan katılımcıların, eczacıların ilaç bilgilendirme görevini yerine getirmesinden memnuniyet düzeyleri daha yüksek olduğu tespit edilmiştir.

Son olarak ilaç kullanımı bilgilendirme boyutunun puanları katılımcıların eczane algılarına göre karşılaştırıldığında istatistiksel olarak anlamlı bir fark olduğu ortaya çıkmıştır $(\mathrm{F}=7,158, \mathrm{p}=0,000)$. Yapılan Tukey's-b testi sonucunda farklılığın eczaneyi ticarethane olarak gören bireylerin ilaç kullanımı hakkında bilgilendirme faaliyetinden memnuniyet düzeylerinin, eczaneyi sağlık kuruluşu ve ilaç alınan yer olarak gören bireylerinkinden daha düşük olmasından kaynaklandığı tespit edilmiştir.

Tablo 7. Fiziki şartlar ve iletişim boyutunun demografik değişkenlere göre karşılaştırması

\begin{tabular}{|c|c|c|c|c|}
\hline Değişkenler & $\mathbf{N}$ & $\bar{X}$ & SS & Test Değerleri \\
\hline \multicolumn{5}{|l|}{ Cinsiyet } \\
\hline Erkek & 176 & 3,938 & 0,847 & \multirow{2}{*}{$\begin{array}{l}\mathrm{t}=0,234 \\
\mathrm{p}=0,815\end{array}$} \\
\hline Kadın & 211 & 3,917 & 0,864 & \\
\hline \multicolumn{5}{|l|}{ Yaş (Yll) } \\
\hline$-\quad 24$ & 82 & 3,758 & 0,813 & \multirow{4}{*}{$\begin{array}{l}F=6,427 \\
\mathbf{p}=\mathbf{0 , 0 0 0}\end{array}$} \\
\hline $25-34$ & 119 & 3,824 & 0,807 & \\
\hline $35-44$ & 72 & 4,000 & 0,901 & \\
\hline $45+$ & 92 & 4,246 & 0,800 & \\
\hline \multicolumn{5}{|l|}{ Medeni Durum } \\
\hline Evli & 231 & 4,038 & 0,862 & \multirow{2}{*}{$\begin{array}{l}\mathrm{t}=3,149 \\
\mathbf{p}=\mathbf{0 , 0 0 2}\end{array}$} \\
\hline Bekâr & 150 & 3,758 & 0,824 & \\
\hline \multicolumn{5}{|l|}{ Eğitim Durumu } \\
\hline İlköğretim & 74 & 4,038 & 0,876 & \multirow{5}{*}{$\begin{array}{l}F=3,146 \\
\mathbf{p}=\mathbf{0 , 0 1 5}\end{array}$} \\
\hline Lise & 64 & 4,104 & 0,920 & \\
\hline Ön Lisans & 37 & 4,130 & 0,873 & \\
\hline Lisans & 160 & 3,837 & 0,842 & \\
\hline Lisansüstü & 51 & 3,673 & 0,687 & \\
\hline \multicolumn{5}{|l|}{ Aylık Gelir (TL) } \\
\hline-1603 & 52 & 4,026 & 0,818 & \multirow{3}{*}{$\begin{array}{l}F=1,947 \\
p=0,122\end{array}$} \\
\hline $1604-3500$ & 127 & 3,980 & 0,873 & \\
\hline $3501-5500$ & 76 & 3,711 & 0,917 & \\
\hline
\end{tabular}




\begin{tabular}{|c|c|c|c|c|}
\hline $5501-$ & 66 & 3,894 & 0,816 & \\
\hline \multicolumn{5}{|l|}{ Çalışma Durumu } \\
\hline Kamu Sektörü & 114 & 3,958 & 0,859 & \multirow{3}{*}{$\begin{array}{l}F=0,674 \\
p=0,511\end{array}$} \\
\hline Özel Sektör & 108 & 3,983 & 0,816 & \\
\hline Diğer & 163 & 3,869 & 0,857 & \\
\hline \multicolumn{5}{|c|}{ Sürekli Aynı Eczaneye Gitme } \\
\hline Evet & 228 & 4.244 & 0,737 & \multirow{2}{*}{$\begin{array}{l}t=9,678 \\
\mathbf{p}=\mathbf{0 , 0 0 0}\end{array}$} \\
\hline Hayır & 157 & 3,474 & 0,811 & \\
\hline \multicolumn{5}{|l|}{ Kronik Hastalık } \\
\hline Evet & 78 & 4,180 & 1,022 & \multirow{2}{*}{$\begin{array}{l}\mathrm{t}=0,875 \\
\mathrm{p}=0,382\end{array}$} \\
\hline Hayır & 322 & 4,076 & 0,932 & \\
\hline \multicolumn{5}{|l|}{ Eczane Algısı } \\
\hline Sağlık Kuruluşu & 68 & 4,272 & 0,773 & \multirow{3}{*}{$\begin{array}{r}\mathrm{F}=16,407 \\
\mathbf{p}=\mathbf{0 , 0 0 0}\end{array}$} \\
\hline Ticarethane & 64 & 3,333 & 0,798 & \\
\hline İlaç Alınan Yer & 250 & 3,972 & 0,823 & \\
\hline
\end{tabular}

Fiziki şartlar ve iletişim boyutunun puanları katılımcıların yaşına göre karşılaştırıldığında istatistiksel olarak anlamlı bir fark olduğu tespit edilmiştir $(\mathrm{F}=6,427, \mathrm{p}=0,000)$. Yapılan Tukey's$\mathrm{b}$ testi sonucunda farkın, 45 yaş ve üzeri bireylerin fiziki şartlar ve iletişim boyutundan memnuniyet düzeylerinin 34 yaş ve altı bireylere göre daha yüksek olmasından kaynaklandığı anlaşılmıştır. Yaşlı bireylerin, eczanenin fiziki şartlarından ve eczacı veya eczane çalışanları ile olan iletişim düzeyinden daha memnun olduğu söylenebilir.

Fiziki şartlar ve iletişim boyutunun puanları katılımcıların medeni durumuna göre karşılaştırıldığında istatistiksel olarak anlamlı bir fark olduğu bulunmuştur $(t=3,146, p=0,002)$. Evli bireylerin, bekâr bireylere göre puanlarının yüksek olduğu görülmüştür.

Fiziki şartlar ve iletişim boyutunun puanları katılımcıların eğitim durumuna göre karşılaştırıldığında istatistiksel olarak anlamlı bir fark olduğu ortaya çıkmıştır $(F=4,251$, $\mathrm{p}=0,002$ ). Yapılan Tukey's-b testi sonucunda farkın, lisansüstü eğitime sahip bireylerin lise ve ön lisans grubundaki bireylere göre daha az memnun olmasından kaynaklandığ tespit edilmiştir. Katılımcıların memnuniyet düzeylerine ilişkin en çok memnun olan grubu ön lisans ve ilköğretim eğitimine sahip bireyler oluştururken en az memnuniyet düzeyine sahip grubun lisansüstü eğitimi görmüş bireylerden oluştuğu sonucuna ulaşılmıştır.

Fiziki şartlar ve iletişim boyutunun puanları katılımcıların sürekli aynı eczaneye gitme durumuna göre karşılaştırıldığında istatistiksel olarak anlamlı bir fark olduğu ortaya çıkmıştır $(\mathrm{t}=9,678, \mathrm{p}=0,000)$. Sürekli aynı eczaneden hizmet alan bireylerin, eczanenin fiziki şartlarından memnuniyet düzeyi daha yüksek iken eczanede kendileri ile ilgilenen kişilerle olan iletişimlerinin de daha yüksek düzeyde olduğu görülmektedir.

Son olarak fiziki şartlar ve iletişim boyutunun puanları katılımcıların eczane algısı durumuna göre karşılaştırıldığında istatistiksel olarak anlamlı bir fark olduğu tespit edilmiştir $(\mathrm{F}=16,407, \mathrm{p}=0,000)$. Yapılan Tukey's-b testi sonucunda farkın, üç grubun da birbirinden farklı olmasından kaynaklandığı anlaşılmıştır. Eczaneyi sağlık kuruluşu olarak görenlerin fiziki şartlardan memnuniyetinin en yüksek olduğu, bunu ilaç alınan yer olarak görenlerin takip ettiği ve ticarethane olarak görenlerin görece olarak memnuniyetlerinin en düşük grup olduğu anlaşılmıştır. 


\section{Tartıșma}

Eczacılık hizmetlerinin değerlendirme anketinin ifadelerine bakılarak; araştırmadaki ifadeler arasında en yüksek "İlaç aldığım eczanenin temizliğinden memnunum" $(4,173 \pm 0,980)$, en düşük ise "İlaç aldığım eczacı ilaçlarımın faydalı olup olmadığ 1 ile ilgili benden geri dönüş alır” $(2,110 \pm 1,310)$ ifadelerinden memnun olunduğu tespit edilmiştir. Benzer bir sonuç Akpınar'ın (2015) çalışmasında da elde edilmiştir. Katılımcılara yöneltilen "Eczacım ilaçlarımın faydalı olup olmadığı ile ilgili bana görüşümü sorar" ifadesine \%46,6 katılım olduğu tespit edilmiştir. Mináriková ve arkadaşları (2016) tarafindan Slovakya'da hasta memnuniyetinin ve serbest eczanelerinin değerlendirilmesi amacıyla yapılan çalışmada da en düşük puan alan ifadelerden birinin bu çalışmada olduğu gibi "İlaçlarınızın ne kadar işe yaradığını eczacı sizinle ne sıklıkla kontrol eder" $(2,69)$ ifadesi olduğu tespit edilmiştir.

Eczacıların sundukları hizmetler arasında ilaç hakkında bilgilendirme, tedaviye yöneltme, tavsiyede bulunma, tedavi sürecini kontrol etme işlevleri bu çalışmada "danışmanlık rolü" boyutunun olarak adlandırılırken, Mináriková ve arkadaşları (2016) tarafından yapılan çalışmada "tedavi yönetimi” olarak adlandırılmıştır. Benzerlik gösteren ifadelere bakıldığında ortalamalarının da yakın değer aldıkları tespit edilmiştir.

Araştırmada danışmanlık rolü boyutunun en düşük ortalama değeri aldığı ortaya çıkmıştır. Benzer şekilde Mináriková ve arkadaşlarının (2016) çalışmasında da bireylerin tedavi yönetiminden memnuniyet düzeylerinin en düşük olduğu saptanmıştır ve Slovakya eczanelerinde hastalık tedavisi veya ilaca bağlı tedavi ile ilgili spesifik danışmanlık yapılmadığı belirtilmiştir. Aynı durumun Isparta ilinde de geçerli olduğunu söylememiz mümkündür. Alhomoud ve arkadaşlarının (2016) yaptıkları çalışmada da danışmanlık ile alakalı boyutun en düşük memnuniyet düzeyine sahip olduğu tespit edilmiştir.

Hasta ile eczacı arasında sözlü olmayan iletişim üzerinde çevresel etmenlerin etili olduğu düşünülmektedir. Mekânın 1şıklandırması, kullanılan renklerin dekorasyonu, ferahlığı, genişliği ve temizliği eczacı ile olan iletişimi etkileyen faktörler olmakla birlikte eczacı hakkındaki algıları da etkilemesi mümkündür (Tindall vd., 1989; Çağırcı ve Yeğenoğlu, 2007, s. 38). Çalışmamızda eczanenin temizliği, ferahlığı ve genişlik olarak yeterli olması gibi fiziki şartları değerlendiren ifadeler ile eczaciyla iletişimden memnuniyeti değerlendiren ifadeler "fiziki şartlar ve iletişim" olarak adlandırılan tek bir boyut altında toplanmıştır. Katılımcıların bu boyuttan iyi derecede memnun oldukları tespit edilmiştir. Bu çalışmada eczanelerin fiziki şartlarının iyi olduğu sonucuna varılmıştır.

Çalışmaya katılan bireylerin yaş değişkenine göre karşılaştırması yapıldığında danışmanlık rolü ve fiziki şartlar- iletişim boyutlarında anlamlı bir farklılık olduğu tespit edilmiştir. Yaş arttıkça bireylerin eczacıların danışmanlık yaptıklarına dair algılarının da yükseldiği ve 45 yaş üstü bireylerin daha memnun oldukları saptanmıştır (Tablo 5). Fiziki şartlar ve iletişim boyutunda da benzer şekilde yaş arttıkça memnuniyet düzeyinin yükseldiği anlaşılmıştır (Tablo 7). Bu durumda yaşlı bireylerde memnuniyetin daha yüksek olduğu sonucuna varılmıştır. Alhomoud ve arkadaşlarının (2016) yaptıkları çalışmada ise yaş artıkça eczacılık hizmetlerinden memnuniyetin azaldığı tespit edilmiştir.

Katılımcıların medeni durumları ile danışmanlık rolü ve fiziki şartlar-iletişim boyutlarının karşılaştırılmasına bakıldığında, her iki boyutta evli bireylerin memnun olma durumları daha yüksek bulunmuştur (Tablo 5, 7). Katılımcıların eğitim durumu ile danışmanlık rolü boyutu karşılaştırıldığında ise en düşük algıya sahip bireylerin, en eğitimli grup olan lisansüstü eğitim seviyesindeki hastalar olduğu tespit edilmiştir. En yüksek algıya sahip gruplar ise ön lisans ve ilköğretim eğitimi alan hastalardan oluştuğu saptanmıştır (Tablo 5).

Katılımcıların eğitim durumunun fiziki şartlar ve iletişim boyutu ile karşılaştırılması sonucu, genel memnuniyet düzeyinin orta derecenin üzerinde iyi olduğu anlaş1lmıştır. Eğitim değişkeni içerisinde en ez memnun olan grubun lisansüstü eğitim alan kişiler olduğu tespit 
edilmiştir (Tablo 7). Alhomoud ve arkadaşlarının (2016) yaptıkları çalışmada ise eğitim seviyesi düşük olan hastaların iletişim kalitesinden memnuniyetlerinin daha düşük olduğu tespit edilmiştir.

Çalı̧̧maya katılan bireylerin \%58,7'si sürekli aynı eczaneye gittiklerinin belirtmişlerdir. Benzer şekilde Yeğenoğlu Onaran'ın (1994) yaptığı çalışmada da katılımcıların \%83'ünün sürekli aynı eczaneye gittiği tespit edilmiştir. Akpınarın (2015) yaptığı çalışmada da katılımcıların \%56,1'inin aynı eczaneye gittiği saptanmıştır. Sürekli aynı eczaneye gitme durumu ile her üç boyut ile karşılaştırıldığında anlamlı bir farklılık olduğu tespit edilmiştir. Sürekli aynı eczaneyi tercih edenlerin eczacıya dair danışmanlık algıları daha yüksek, eczanenin fiziki şartlarından ve eczacı ile ilan iletişimden daha memnun, eczacını ilaç kullanımı bilgilendirmesinden de daha memnun oldukları saptanmıştır. Sürekli aynı eczaneye gitme durumu zamanla daha güçlü iletişim kurulmasına, tanışık olma durumunun gerçekleştirilmesine, hastanın rahatsızlıklarının eczacı tarafından daha bilinir ve izlenebilir duruma gelmesine ve de zamanla güven ortamının kurulması ile eczacıdan tavsiye alma noktasında gelişmelerin yaşanmasına yol açabilir. Tüm bu durumlar memnuniyeti etkileyen faktörler olarak görülebilir. Ayrıca bu durumlar zamanla eczacıyı istenilen profesyonel danışman statüsüne de getirme açısından önemli olduğu söylenebilir.

Yeğenoğlu Onaran'ın (1994) yaptı̆̆ çalışmada katılımcıların \%17 si eczacıları tüccar olarak tanımlarken \%83'ü sağlıķı olarak tanımlamışlardır. Bu çalışmada da katılımcıların eczane algısını ölçmek için eczaneyi nasıl bir yer olarak tanımladıkları sorulmuştur. Katılımcıların \%64,9 "ilaç alınan yer" olarak tanımlarken, \%16,8'lik gibi küçük bir grup (68 kişi) "ticarethane" olarak gördügünü belirtmiştir. Ankette yer alan açık uçlu soruda da tekrardan vurgulamak isteyen 18 kişi "eczanelerin ticarethane mantığıyla çalıştığını, eczacıların paragöz olduklarını, eczacıların esnafa dönüştüğünü ve hastayı müşteri olarak gördüklerini” belirtmişlerdir. Ancak katılımcıların büyük çoğunluğunun böyle düşünmediği ilaç aldıkları yer olarak gördükleri tespit edilmiştir. Eczanelerin ilaç satılan yer olarak görülmesine paralel olarak katılımcılar eczacıları ilk sırada "ilaç satıcısı" olarak tanımlamışlardır.

Eczanelere ilaç alınan yer başka bir deyişle ilaç satılan yerler olarak bakıldığında eczanelerin ticaret yaptı̆̆ını söylemek mümkün olur. Lakin katılımcıların eczaneleri ticarethaneden ziyade ilaç alınan yer olarak belirtmeleri eczanelerin imajı açısından olumlu olarak değerlendirilebilir. İki tanı arasındaki nüans farkı katılımcılarca fak edilmiş olup eczanelerin sağlı hizmeti sağlamanın yanında ticari özelliği olsa bile eczanenin ticarethane olmadığı sayısal verilerle ortaya konulmuştur.

Anket uygulaması esnasında katılımcıların çoğu "eczacımıza soru sorarsak cevap veriyor." ibaresini kullanmışlardır. Araştırmamızda da ifadeler arasında yer alan "İlaç aldı̆̆ım eczacı soru sormam için uygun fırsatları oluşturur." (3,097) ifadesine katılım orta düzeyin altında kalmıştır. Ayrıca anket geliştirme aşamasında eczacılarla yapılan görüşmeler esnasında eczacıların da benzer bir ifade kullandıkları tespit edilmiştir. Benzer şekilde El Hajj ve arkadaşlarının (2011) yaptığı çalışmada "Reçeteli ilaçlarımı satın aldığımda eczane bana reçetemi veriyor, ilaç tedavisi konusunda bana rehberlik ediyor ve soru sormamı teşvik ediyor." $(2,02)$ ifadesinden memnuniyet düzeyi düşük bulunmuştur. Alhomoud ve arkadaşlarının (2016) yaptıkları çalışmada da benzer şekilde eczacıların "ilaç danışmanlığı sağlamak ve hastaları ilaçlarla ilgili sorular sormaya teşvik etmek" ifadesi en düşük puanı almıştır. Tüm bu tespitler değerlendirildiğinde eczacıların iletişim için ilk adımı hastalardan beklediği sonucuna varılabilir.

\section{Sonuç ve Öneriler}

$\mathrm{Bu}$ çalışmada bireylerin, eczacılık hizmetlerine dair beklentilerinin karşılanıp karşılanmadığını değişen eczacı rolleri bağlamında değerlendirmeleri istenmiştir. Çalışma kapsamında Isparta il merkezinde ikamet eden toplam 411 kişiye ulaşılmıştır. Araştırmacı tarafından oluşturulan anketin ifadeleri faktör analiz sonucunda 3 boyutta toplanmıştır. İlk faktör olan danışmanlık rolü boyutunda eczacının, hastaya ilaçların yan etkisini ve ilaç uyumunu anlatması, hastadan ilaç ve sağlığı konularında geri dönüt alması ve sağlıklı yaşam başta olmak üzere çeşitli tavsiyelerde bulunması gibi görevleri içeren 15 ifade yer almıştır. İkinci faktör olan 
fiziki şartlar ve iletişim boyutunda hem eczanenin fiziki şartları hem de eczacı ile hasta arasındaki iletişim 6 ifade ile değerlendirilmiştir. Son faktör olan ilaç kullanımı bilgilendirme boyutunda eczacının hastalara ilacı nasıl kullanmaları gerektiğini anlatıp, anlayıp anlamadıklarını ölçen 2 ifade yer almıştır.

Özellikle gelişmiş ülkelerde 1970'lerden beri hastaya yönelik hizmet anlayışı ile eczacılık hizmetlerinin sunulmaya başlaması ile birlikte birinci basamak sağlık hizmeti sunumu bağlamında başarılı bir gelişme kat edilmiştir. Hastaya yönelik eczacılık hizmeti dönemi olarak adlandırılan günümüzde eczacılardan ilaç ve sağlık konularında tavsiyelerde bulunmaları, yönlendirme yapmaları ve hastaları kontrol altında tutmaları beklenmektedir.

Araştırmada eczacılık hizmetleri, öncelikle danışmanlık rolü boyutunda ele alınmıştır. Ayrıca hastaların eczacı ile olan iletişimleri, eczanenin fiziki şartları ve eczacının klasik görevi olarak kabul edilen ilaç bilgilendirme boyutları hastalar tarafından değerlendirilmiştir. Hastaların en çok memnun oldukları konunun ilaç kullanımı bilgilendirmesi olduğu tespit edilmiştir. Hastaların fiziki şartlar ve iletişim boyutundan memnuniyetlerinin iyi düzeydeyken, değişen eczacılık rollerinin değerlendirilmesinin alındığ danışmanlık rolü boyutunda hastaların algılarının orta düzeyde olduğu bulunmuş̧tur. Ayrıca hastalar ve eczacılar ile yapılan görüşmeler ve de anket sonucunda eczacıların iletişim için ilk adımı hastalardan beklediği tespit edilmiştir.

Araştırma sonucunda eczacıların değişen roller bağlamında hizmet sunumunda yetersiz oldukları, hastaların eczacıların danışmanlıklarından orta derecede memnun oldukları sonucuna varılmıştır. Ancak eczanelerin fiziki şartlarının iyi olduğu, hastalarla iletişim noktasında hastaları memnun ettikleri ve ilaç kullanımı hakkındaki bilgilendirme yaptıkları tespit edilmiş ve hastaların genel olarak bu noktalarda yüksek derecede memnun oldukları bulunmuştur.

Demografik değişkenlerden yaş grubuna bakıldığında yaş arttıkça, bireylerin eczacılara ilişkin danışmanlık rolü algılarının da yükselme eğiliminde olduğu sonucuna varılmıştır. Yine hastaların yaşı arttıkça fiziki şartlardan memnuniyet düzeylerinin yükseldiği ve eczacılar veya eczane çalışanları ile daha tatmin edici iletişim gerçekleştirdikleri sonucu elde edilmiştir. Yaşlı bireylerin eczacılık hizmetlerinden genel olarak daha memnun oldukları sonucuna ulaşılmıştır. Bir diğer sonuç olarak da, eğitim seviyesi yüksek bireylerin eczacıların danışmanlık yaptıklarına dair algıları orta düzeyde çıkarken, eczanenin fiziki şartlarından ve eczane çalışanları ile olan iletişimden memnuniyet düzeylerinin iyi olmakla birlikte diğer gruplara göre daha düşük olduğu sonucuna varılmıştır.

Araştırmanın sonuçlarından ve katılımcıların önerilerinden hareketle aşağıdaki öneriler geliştirilmiştir:

- Farmasötik bakım içerisinde değerlendirilebilecek danışmanlık rolünden memnuniyet orta düzeyde bulunmuştur. Ancak daha kaliteli ve günümüz şartlarına uygun hizmet sunumu için eczacılar, hasta merkezli anlayışa uygun şekilde davranışlarını değiştirmelidir.

- Serbest eczacıların, toplum sağlığının korunması ve geliştirilmesine katkı sunma kapasitelerini geliştirecek olan klinik eczacılık uygulamaları ve farmasötik bakım süreçleri meslek içi eğitim programları ile desteklenmelidir. Böylece bu konularda eczacıların bilgi düzeyleri arttırılabilir.

- Eczacılık hizmetlerinden memnuniyetin sağlanması ile ilaç tedavisinde uyunç artmakta, ilaç yan etkilerinin yol açtı̆̆ sorunlar giderilebilmekte ve tedavinin başarıyla sonuçlanma ihtimali yükselmektedir. Eczacıların bu durumların farkında olması sağlanmalıdır.

- Türk Eczacılar Birliği'nin yürütmekte olduğu Rehber (Smart) Eczanem projesi daha yaygın hale getirilmeli ve benzer projelerle eczacıların değişen rollerini yerine getirebilmeleri için eğitim desteği sağlanmalıdır.

- Eczacılar, klasik ilaç verme ve ilacın üzerine kullanışının yazma görevlerinin yanı sıra hastaya yönelik danışmanlık hizmetleri de vermeli ve hastalara danışmanlık yapmak için daha fazla zaman ayırmalıdırlar. 


\section{Kaynakça}

ACCP (American College of Clinical Pharmacy). (2008). The definition of clinical pharmacy. Pharmacotherapy, 28(6), 816-817.

Adamcik, B.A., Ransford, H.E., Oppenheimer, P.R., Brown, J.F., Eagan, P.A.ve Weissman, F.G. (1986). New clinical roles for pharmacists: a study of role expansion. Social Science \& Medicine, 23(11), 1187-1200.

Akpınar, S. (2015). Hasta- eczacı ilişkisi algı düzeyi ile hastanın eczaneye güveni, sadakati ve memnuniyeti arasındaki iliş̧ki (Yayımlanmamış yüksek lisans tezi). Beykent Üniversitesi, İstanbul.

Alhomoud, F.K., Kunbus, A., Ameer, A. ve Alhomoud, F. (2016). Quality assessment of community pharmacy services provided in the united arab emirates: patient experience and satisfaction. Journal of Applied Pharmaceutical Science, 6(3), 17-23.

Atilla, G. (2012). Hastanelerde duygusal zekâ-hasta memnuniyeti ilişkisi: Isparta İl merkezi örneği (Yayımlanmamış doktora tezi). Süleyman Demirel Üniversitesi, Isparta.

Aypar, E., Sancar, M. ve İzzettin, F.V. (2014). Eczac1lıkta yeni dönem: klinik eczacılık ve sağlık sistemindeki yeri. Sağlık Düşüncesi ve Tip Kültürü Dergisi, 30 (Mart-Nisan-Mayıs), 48-51.

Barber, N., Smith, F. ve Anderson, S. (1994). Improving quality of health care: the role of pharmacists. Quality in Health Care (QHC), 3(3), 153-158.

Baytop, T. (1995). Eczâhâne'den eczane'ye: Türkiye'de eczaneler ve eczacılar (1800-1923), İstanbul.

Berenguer B., La Casa C., de la Matta M.J. ve Martin-Calero M.J. (2004). Pharmaceutical care: past, present and future. Current Pharmaceutical Design, 10(31), 3931-3946.

Çağırcı, S. ve Yeğenoğlu, S. (2007). Genel İletişsim bilgileri perspektifinden hasta-eczacı iletişimi. Ankara Ecz. Fak. Derg., 36(1), 31-46.

Carr-hill, R.A. (1992). The measurement of patient satisfaction. Journal of Public Health Medicine, 14(3), 236-249.

Dişçi, R. (2008). Temel ve klinik biyoistatistik. (1. Bask1). İstanbul: İstanbul Tıp Kitabevi.

Eczacının Sesi (e-gazete). http://eczacininsesi.com/index.php?yon=dosya\&id=229 (Erişim tarihi: 13.10.2018).

El Hajj, S.M., Salem, S. ve Mansoor, H. (2011). Public's attitudes towards community pharmacy in Qatar: a pilot study. Patient Preference and Adherence, 5, 405-422.

Engiz, O. (1997). Sağlık hizmetlerinde hasta tatmini. O. Hayran ve H. Sur (Eds), Hastane yöneticiliği içinde. İstanbul: Nobel Tip Kitapevleri Ltd.

Ghose, S. ve Adhish, S.V. (2011). Patient Satisfaction with medical services: a hospital-based study. Health and Population: Perspectives and Issues, 34(4), 232-242.

Gourley, G.K., Gourley, D.R., La Monica Rigolosi, E., Reed, P., Solomon, D.K. ve Washington, E. (2001). Development and validation of the pharmaceutical care satisfaction questionnaire. The American Journal of Managed Care, 7(5), 461-466.

Güllülü, U., Erçiş, A., Ünal, S. ve Yapraklı, Ş. (2008). Sağlık hizmetlerinde müşteri memnuniyeti. Ankara: Detay Yayıncilık.

Güngör, S. (2015). Bu devirde eczacıllk. (2. Baskı). Ankara: Artıfarma Yayınları. 
Hepler, C.D. (2004). Clinical pharmacy, pharmaceutical care, and the quality of drug therapy. Pharmacotherapy, 24(11), 1491-1498.

Hepler, C.D. ve Strand, L.M. (1990). Opportunities and responsibilities in pharmaceutical care, American Journal of Hospital Pharmacy, 47(Mar), 533-543.

Hücum, H. (2015). Kronik hastalı̆̆ olanların hasta odaklı eczacıllk hizmetleri ile ilgili memnuniyetlerinin değerlendirilmesi, (Yayımlanmamış yüksek lisans tezi). Marmara Üniversitesi, İstanbul.

Ives, T.J. ve Maddux, M.S. (2004). Defining clinical pharmacy. American College of Clinical Pharmacy Report, 23(2).

Johnson, J.A., Coons, S.J. ve Hays, R.D. (1998). The structure of satisfaction with pharmacy services. Medical Care, 36(2), 244-250.

Kan, İ. (2016). Biyoistatistik. (4. Bask1). İstanbul: Nobel Yayınları.

Kaplanoğlu, E. (2014). Mesleki stresin temel nedenleri ve muhtemel sonuçları: Manisa ilindeki SMMM'ler üzerine bir araştırma. Muhasebe ve Finansman Dergisi, (Ekim), 131-150.

Kassam, R., Collins, J.B. ve Berkowitz, J. (2012). Patient satisfaction with pharmaceutical care delivery in community pharmacies. Patient Preference and Adherence, 6, 337-348.

Kavuncubaşı, Ş. ve Yıldırım, S. (2012). Hastane ve sağllk kurumları yönetimi. (3. Baskı). Ankara: Siyasal Kitapevi.

Kucukarslan, S. ve Schommer, J.C. (2002). Patients' expectations and their satisfaction with pharmacy services. Journal of the American Pharmaceutical Association, 42(3), 489-496.

MacKeigan, L.D. ve Larson, L.N. (1989). Development and validation of an instrument to measure patient satisfaction with pharmacy services. Medical Care, 27(5), 522-536.

Mináriková, D., Malovecká, I., Lehocká, L., Snopková, M. ve Foltán, V. (2016). The assessment of patient satisfaction and attendance of community pharmacies in Slovakia. European Pharmaceutical Journal, 63(2), 23-29.

Oliver, R. L. (1997). Satisfaction: a behavioural perspective on the consumer. ( $2^{\text {nd }}$ Edition). New York: McGraw Hill.

Özkan Aydın, N., Çoban, S. ve Mordoğan, H. (2011). Malatya ă̆ız ve dişs sağlığı merkezinde hasta memnuniyeti. II. Uluslararası Sağlıkta Performans Ve Kalite Kongresi Poster Bildiriler Kitabı, (ss. 212-217), Ankara: Azim Matbaacılık.

Ross, C.K., Frommelt, G., Hazelwood, L. ve Chang, R.W. (1987). The role of expectations in patient satisfaction with medical care. Journal of Health Care Marketing, 7(4), 16-26.

Sakharkar, P., Bounthavong, M., Hirsch, J.D., Morello, C.M., Chen, T.C. ve Law, A.V. (2015). Development and validation of PSPSQ 2.0 measuring patient satisfaction with pharmacist services. Research in Social and Administrative Pharmacy, 11(4), 487-498.

Shirkey, H.C. (1977). Clinical pharmacy- past, present and future. Drug Intelligence and Clinical Pharmacy, 11, 674-677.

Sitzia, J. ve Wood, N. (1997). Patient satisfaction: a review of 1ssues and concept. Social Science \& Medicine, 45(12), 1829-1843.

Tanker, M. (1984). Dünden bugüne eczac1lk ve ilaç. Pharmacia, 2, 77-80.

TEB. (2003). Serbest eczacıların sürekli meslek içi eğitimine ilişsin görüşleri. (Say1 5), Ankara: Türk Eczacılar Birliği. 
TEB, (2007). Eczacının sağlık sektöründeki konumu ve mesleğin genel sorunları. içinde:TEB, Düşük cirolu serbest eczaneler araştırmast. (ss. 27-32). Ankara: Fersa Matbaacılik.

Tengilimoğlu, D. (2001). Sağlık kuruluşlarında halka ilişsiler. Ankara: Gazi Kitabevi.

Tindall, W.N., Beardsley, R.S. ve Kimberlin, C. (1989). Communication skills in pharmacy practice. Pennsylvania, USA: Lea\&Febiger.

TÜİK (Türkiye İstatistik Kurumu). 2017. www.tuik.gov.tr (Erişim tarihi: 17.11.2018).

Üney, A. (2016). Sağlık ilaç ve ezacılık istatistikleri yıllığı. Ankara: Türk Eczacıları Birliği.

White, E.V. ve Latif, D.A. (2006). Office-based pharmacy practice: past, present, and future. The Annals of Pharmacotherapy, 40(July/August), 1409-1414.

WHO. (1994). The role of the pharmacist in health care reform. WHO.

Wiedenmayer, K., Summers, R.S., Mackie, C.A., Gous, A.G.S.ve Everard, M. (2006). Developing pharmacy practice: a focus on patient care. HANDBOOK-2006 edition with contributions from, Geneva, Switzerland.

Yeğenoğlu Onaran, S. (1994). Toplumun eczacllı hizmetlerine iliş̧kin bilgi ve beklentileri konusunda bir araştırma (Bilim uzmanlığı tezi). Hacettepe Üniversitesi, Ankara.

27125 Sayılı 2008 Yılı Sosyal Güvenlik Kurumu Sağlık Uygulama Tebliği Değişiklik Yapılmasına Dair Tebliğ, R.G. Tarihi: 29/1/2009.

28970 sayılı Eczacılar ve Eczaneler Hakkında Yönetmelik. İyi Eczacılık Uygulamaları Kılavuzu (50. md.).

\section{ETIK ve BİLIMSEL İLKELER SORUMLULUK BEYANI}

$\mathrm{Bu}$ çalışmanın tüm hazırlanma süreçlerinde etik kurallara ve bilimsel atıf gösterme ilkelerine riayet edildiğini yazar(lar) beyan eder. Aksi bir durumun tespiti halinde Afyon Kocatepe Üniversitesi Sosyal Bilimler Dergisi'nin hiçbir sorumluluğu olmayıp, tüm sorumluluk makale yazarlarına aittir. Yazarlar etik kurul izni gerektiren çalışmalarda, izinle ilgili bilgileri (kurul adı, tarih ve sayı no) yöntem bölümünde ve ayrıca burada belirtmişlerdir.

Kurul adı: Süleyman Demirel Üniversitesi Rektörlüğü Sosyal ve Beşeri Bilimler Etik Kurul Başkanlığ 1

Tarih: 13.11.2018

No: $87432956 / 050.99 / 274373$ 